\title{
CHOLINERGIC MODULATION OF SINGLE LATERAL GENICULATE NEURONS IN THE CAT*
}

\author{
I. MATSUOKA t and E. F. DOMINo \\ Michigan Neuropsychopharmacology Research Program, \\ Department of Pharmacology, University of Michigan, \\ Ann Arbor, Michigan 48104
}

(Accepted 27 July 1971)

\begin{abstract}
Summary-The effects of physostigmine, nicotine and scopolamine were studied on the activity of single lateral geniculate neurons in the acute cat. Most of the lateral geniculate neurons selected were P-celis. These increased their responses to ipsilateral optic tract and midbrain reticular formation stimulation.

Nicotine and physostigmine in doses of $25 \mu \mathrm{g} / \mathrm{kg}$ i.v. significantly increased the spontaneous firing rate of single geniculate neurons. Scopolamine in a dose of $0.5 \mathrm{mg} / \mathrm{kg}$ i.v. depressed their firing rates to control levels. Physostigmine enhanced their post-stimulus discharge rate to optic nerve stimulation. This enhancement was depressed by scopolamine. The effects of midbrain reticular formation stimulation were further enhanced by physostigmine and reduced by scopolamine in about $86 \%$ of lateral geniculate neurons studied. Generally, the effects of trains of pulses to the reticular formation $(250 \mathrm{~Hz} / \mathrm{sec}, 50 \mathrm{msec}$ train duration, $0 \cdot 05-0 \cdot 1 \mathrm{msec}$ pulses) were more marked than single stimuli.

It is concluded that a major cholinergic facilitatory system exists which influences lateral geniculate neurons. It is postulated that this involves the reticular formation. Evidence is presented for a predominant muscarinic cholinergic mechanism.
\end{abstract}

IT is well known that the lateral geniculate nucleus contains catecholamines, 5-hydroxytryptamine (AMIN, Crawford and GAdDIN, 1954; Vogt, 1954; Bogdanski, Weissbach and Udenfriend, 1957; Cobbin, Leeder and Pallord, 1965; FuXe, 1965; Shute and LEWIS, 1966), acetylcholine, cholinesterase and choline acetyltransferase (BURGEN and Chipman, 1951; Feldberg and Vogt, 1948; Hebb and Silver, 1959; DefFenu, Bertaccini and PePEU, 1967; SHUTE and LewIS, 1963, 1966). Electrophysiological and iontophoretic studies of lateral geniculate neurons indicate that monoamines usually depress these cells (Curtis and Davis, 1962; DefFenu et al., 1967; Phillis, Tebecis and York, 1967a). Curtis and DAvis (1963) and PhILlis, Tebecis and YORK (1967b) reported that about $50 \%$ of these neurons were excited by acetylcholine and only $4 \%$ depressed.

Bishop, LeVicK and WiLliams (1964) and LeVICK and WiLliams (1964) reported on the interspike distribution of single lateral geniculate units. In addition, GERSTEIN and LIANG (1960), SATINSKY (1968) and CHOW, LINDSLEY and Gollender (1968) have described the post-stimulus histogram of lateral geniculate neurons to afferent stimuli.

The purpose of the present study was to investigate the effects of certain cholinergic agonists and antagonists on single lateral geniculate P-cell discharge. Both spontaneous neuronal activity and that evoked by optic tract and reticular stimulation were analyzed

*Supported in part by a grant from the Council for Tobacco Research, U.S.A.

$\dagger$ Present address: Department of Otorhinolaryngology and Pharmacology, Faculty of Medicine, Kyoto University, Kyoto, Japan. 
using on-line digital computer techniques for determining the post-stimulus histograms of these cells.

\section{METHODS}

Twenty-two adult cats of either sex, weighing $2 \cdot 5-4 \mathrm{~kg}$, were used. Each was anesthetized with diethyl ether-air for all surgical procedures. A pair of steel bipolar electrodes was inserted stereotaxically into the right optic tract (A. 11.0, L. 7.0, H. -4.0) and the mesencephalic reticular formation (A. $2 \cdot 0$, L. 3·0, H. $-1 \cdot 0)$ with the aid of SNIDER and NIEMER's (1961) stereotaxic brain atlas. A pair of silver wire electrodes were placed in the visual cortex on the right side, $3 \mathrm{~mm}$ under the surface. By this means the visual cortex was stimulated with single shocks to evoke antidromic unit activity of lateral geniculate cells. Orthodromic responses to optic nerve stimulation were also obtained from the same cells.

After completion of the operative procedure the animal was given local anesthesia (0.5\% lidocaine) at all wound edges and immobilized with i.v. decamethonium (0.5-1 $\mathrm{mg} / \mathrm{kg} / \mathrm{hr}$ ). Artificial respiration was maintained and body temperature was kept at $36-37^{\circ} \mathrm{C}$ by means of an automatic heating pad (Gorman-Rupp Industries, Inc., Model K-1-3). Under these conditions, the mean \pm S.E. of the animal blood $\mathrm{pH}, \mathrm{pO}_{2}$ and $\mathrm{pCO}_{2}$ was as follows: $\mathrm{pH}=7.37 \pm 0.01, \mathrm{pO}_{2}=101.00 \pm 5.74 \mathrm{~mm} \mathrm{Hg}$ and $\mathrm{pCO}_{2}=36.00 \pm 6.37 \mathrm{~mm} \mathrm{Hg}$ (respiration volume, $250 \mathrm{ml}$, respiration rate, $22 / \mathrm{min}$ and sample number, 4). These values were almost the same as those of normal arterial blood. Arterial BP was recorded by means of a transducer from the right femoral artery.

Single square wave pulses $(0.05 \mathrm{msec}, 10 \mathrm{~V})$ were applied to the right optic tract. The evoked responses in the ipsilateral visual cortex were recorded simultaneously with a Grass P-5 amplifier and displayed on a Tektronix dual beam oscilloscope. Single square wave pulses $(0.1 \mathrm{msec}, 5 \mathrm{~V})$ were applied to the mesencephalic reticular formation $50 \mathrm{msec}$ prior to optic tract stimulation to observe their facilitating effects (NAKAI and DomINO, 1968, 1969). Recording of unitary discharges was begun 3-4 hr after termination of diethyl ether anesthesia. Unitary activity of lateral geniculate neurons was recorded with tungsten and steel microelectrodes. These were prepared as described by HuBEL (1957) and BoudREAU, BIERFR and KAUfman (1968). Electrode resistance was 1-10 M $\Omega$. The microelectrodes were inserted stereotaxically into the right lateral geniculate (A. 7.5, L. 10.5, H. 3.0).

Evoked responses to the optic tract and antidromic stimulation were recorded as described by VASTOLA (1957), IWAMA, SAKaKura and KASAMATSU (1965), and SAKaKura and IWAMA (1967). The microelectrode was connected to a cathode follower, Grass P-5 amplifier and displayed on a Tektronix dual beam oscilloscope. A peak detector converted action potentials into pulses of constant amplitude and duration (TMC, Models 605 and 607). These were fed into a TMC CAT $400 \mathrm{~B}$ and written out on a printer, Model 500A. On-line post-stimulus time histograms of single unit activity were thus obtained. At the end of each experiment, a current of $22.5 \mathrm{~V}$ d.c. was applied for $20 \mathrm{sec}$ to the microelectrode and the brain was fixed with $12.5 \%$ formaldehyde for subsequent histologic examination. All experiments were done under dark room conditions. In some experiments both eyeballs were enucleated to rule out drug effects on the retina.

\section{RESULTS}

Typical evoked responses in the visual cortex were obtained by single electrical stimuli to the right optic tract (BISHOP and O'LEARY, 1938, 1940; BisHOP, 1953; BISHOP and MACLEOD, 1954 ; Suzuki, TaIra and Motokawa, 1960; NAKAI and Domino, 1968, 1969). Stimulation 
of the reticular formation just prior to optic tract stimulation also enhanced these responses (Angel, Magni and Strata, 1965a,b, 1967a,b; Chi and Flynn, 1968; Long, 1959; Nakai and Domino, 1968, 1969; OGAWA, 1963; SUzuKI and TAIRA, 1962; SuZuki and Ichijo, 1967).

Evoked potentials to optic tract stimulation in the visual cortex and lateral geniculate were observed in every experiment in order to obtain electrophysiological evidence that the electrodes were properly located before recording unitary activity.

\section{Spontaneous firing rate of lateral geniculate neurons}

The criteria for identifying a lateral geniculate unit were a spike response with a relatively short and fixed latency (less than $1.5 \mathrm{msec}$ ) and a response to diffuse illumination of the eye with an "on" or "off" discharge (BISHOP, BURKE and DAVIs, 1962; SUZUKI and ICHIJo, 1967; CHow et al., 1968). Eleven lateral geniculate neurons with latencies over $1.5 \mathrm{msec}$ were omitted from this study. All lateral geniculate neurons responded to ipsilateral light stimulation. Most of them responded as "on", "on-off", or "off" types (ADRIAN and MATTHEws, 1927a,b, 1928; Hartline, 1938; Hubel and Wiesel, 1962; McIlwain and Creutzfeldt, 1967; Erulkar and Fillenz, 1958; Kahn, Magni and Pillai, 1967; Chow et al., 1968). The mean spontaneous firing rate \pm S.E. of 63 lateral geniculate neurons under dark conditions was $22 \cdot 35 \pm 1.90 \mathrm{sec}$ (Fig. 1). This frequency is almost the same as that reported by Bishop et al. (1964), Suzuki and ICHIo (1967), Levick and Williams (1964) and Chow et al. (1968).

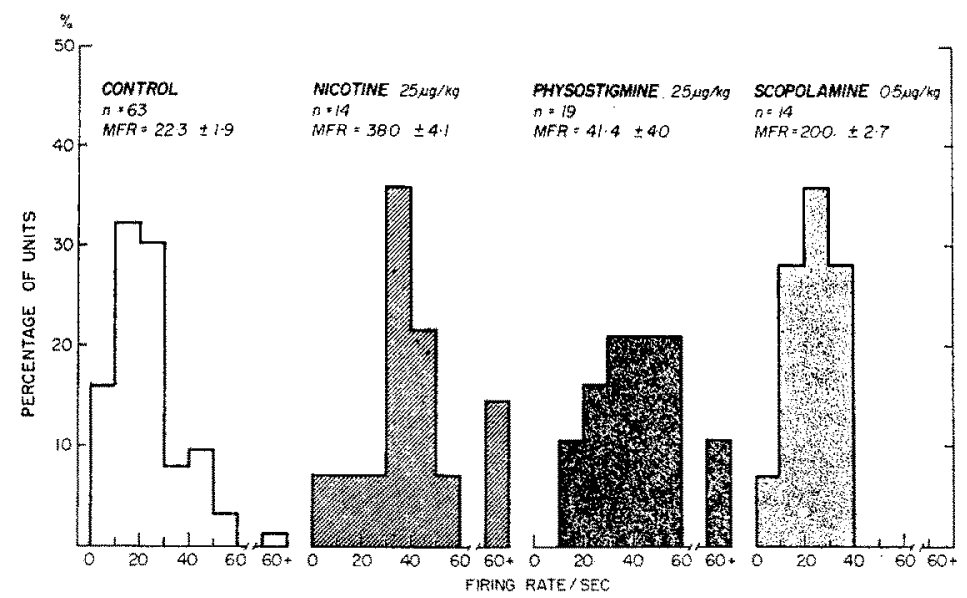

FIG. 1. Frequency distribution of spontaneous unit discharge of lateral geniculate neurons following various cholinergic agonists and antagonists. On the $\mathrm{x}$-axis is shown the frequency/sec and on the $y$-axis the percentage of P-cells $(n=63)$ before and after various drugs as noted. The data for nicotine was obtained $2 \mathrm{~min}$ after, that for physostigmine $5 \mathrm{~min}$ after, and that for scopolamine $5 \mathrm{~min}$ after i.v. injection. Note that nicotine and physostigmine increased the spontaneous firing rate and scopolamine reduced it toward control levels. MFR, mean firing rate \pm S.E.

\section{Unit responses to single optic tract stimulation}

Post-stimulus time histograms were recorded for 37.5 and $500 \mathrm{msec}$. The data were subdivided into $12.5 \mathrm{msec}$ intervals and analyzed statistically using the Student's $t$-test. 
Analysis time $37.5 \mathrm{msec}$. Thirty-four lateral geniculate neurons responded to optic nerve tract stimulation as follows: 28 units $(82.6 \%)$ increased, 3 units $(8.7 \%)$ decreased, and 3 units $(8.7 \%)$ did not change their firing rate to the single shocks to the optic tract. A latency of $0.75-1 \mathrm{msec}$ to single optic tract stimulation was observed most frequently as shown in Figs. 2 and 3.

Analysis time 500 msec. Eighteen lateral geniculate neurons which responded to optic nerve tract stimulation were classified as follows: 4 lateral geniculate neurons $(22.5 \%)$ decreased and $14(77 \cdot 5 \%)$ increased their firing rates to optic tract stimulation.

\section{Unit responses to single shocks to the reticular formation}

Analysis time $37.5 \mathrm{msec}$. Thirty-four lateral geniculate neurons which responded to single reticular stimulation were classified as follows: 22 units $(64.5 \%)$ increased, 3 units $(8.7 \%)$ decreased, and 9 units $(26.8 \%)$ did not change their firing rate. A latency of about
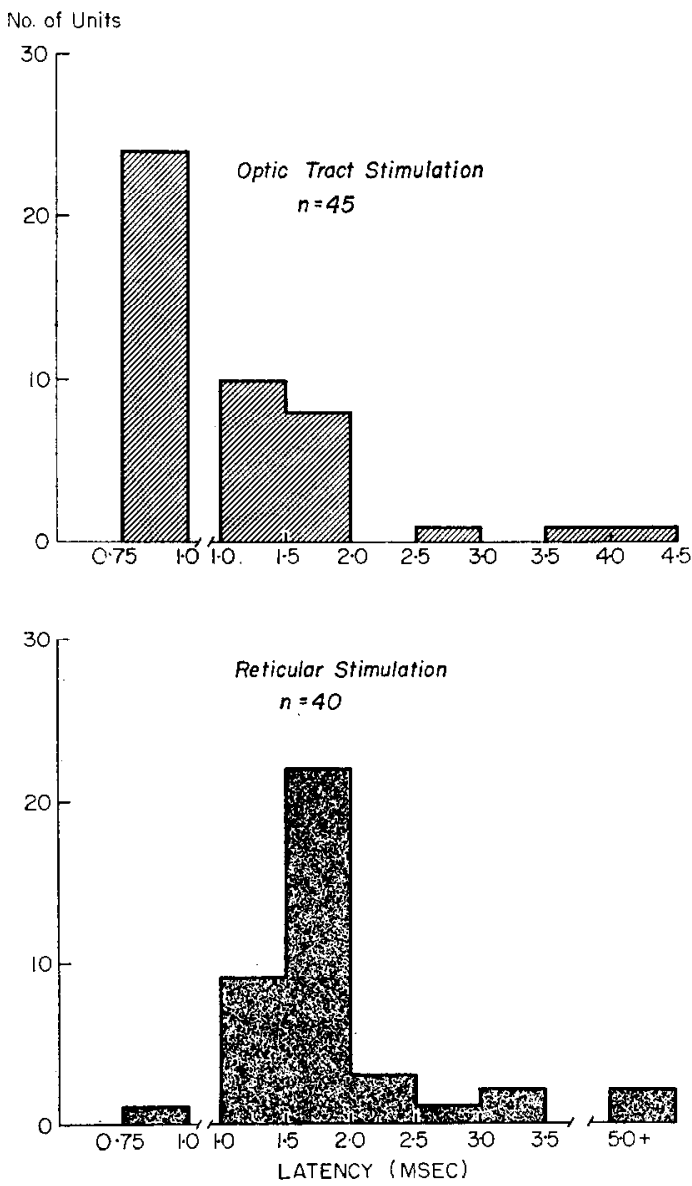

FIG. 2. Latency of lateral geniculate discharge to optic tract and reticular stimulation. The distribution of cell discharges are plotted as a function of latency after stimulation. Note that, as expected, optic tract stimulation resulted in shorter discharge latencies than reticular formation stimulation. The shortest latency to discharge for optic tract stimuli was $0.75 \mathrm{msec}$ and usually at least 1 or more msec for reticular stimulation. 

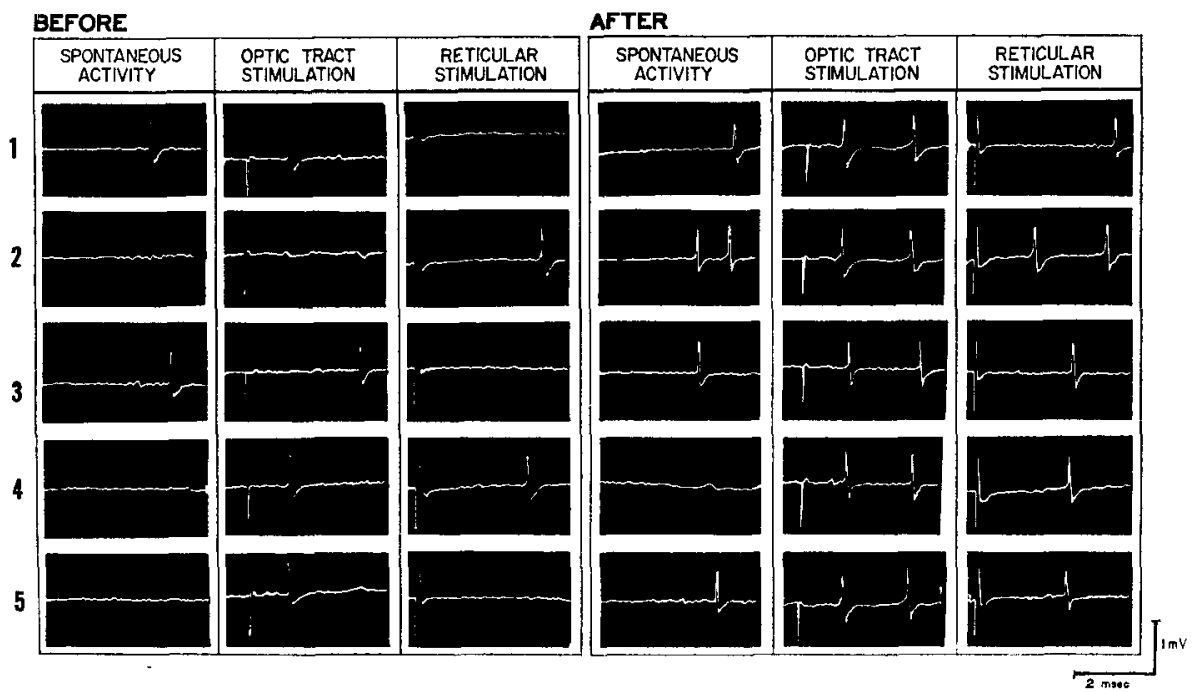

FIG. 3. Effects of physostigmine on spontaneous and elicited single unit activity in the lateral geniculate. A lateral geniculate neuron (P-cell) was recorded before drug under no stimulation in the dark and following single square wave pulses to the ipsilateral optic tract $(0.05 \mathrm{msec}, 5 \mathrm{~V})$ and midbrain reticular formation $(0.1 \mathrm{msec}, 5 \mathrm{~V})$. Time and voltage calibration as shown. Note that after $25 \mu \mathrm{g} / \mathrm{kg}$ of physostigmine the unit was much more responsive.

$1 \cdot 75-2 \mathrm{msec}$ from the beginning of stimulation to the onset of effects was obtained most frequently (Fig. 2).

Analysis time $500 \mathrm{msec}$. Eighteen lateral geniculate neurons which responded to reticular formation stimulation were classified as follows: 14 units $(77.5 \%)$ increased, 3 units $(17.0 \%)$ decreased, and 1 unit $(5.5 \%)$ did not change their firing rate. The latency from the beginning of reticular stimulation to the onset of effect was about $2 \mathrm{msec}$ and lasted much longer (Fig. 2).

\section{Effects of nicotine}

Modification of mean spontaneous firing rates. Unit responses were recorded 2 min after the i.v. administration of $25 \mu \mathrm{g} / \mathrm{kg}$ of nicotine. After nicotine the mean arterial BP rose rapidly to about $60-88 \mathrm{~mm} \mathrm{Hg}$ above control levels and lasted for about $60-80 \mathrm{sec}$. Nicotine caused 14 units to increase their mean spontaneous firing rate $\pm S$.E. to $38 \cdot 00 \pm 4 \cdot 18 / \mathrm{sec}$. This value was significantly higher than for the control group $(22 \cdot 3 \pm 1 \cdot 9 . P<0 \cdot 001)$.

Modification of unit responses to optic tract stimulation. Fourteen lateral geniculate neurons which responded to optic tract stimulation were studied. Nicotine in doses of 25 $\mu \mathrm{g} / \mathrm{kg}$ i.v. caused 9 neurons $(64 \cdot 3 \%)$ to enhance their response rates to single optic tract stimuli. The majority of neurons excited by optic tract stimulation responded within 3 msec. After 2-3 msec of an excitatory phase there was an inhibitory phase of 3-4 msec duration (Fig. 4). Five neurons $(35.7 \%)$ excited by optic tract stimulation were not enhanced by nicotine.

Modification of unitary responses to single reticular stimuli. Following nicotine (25 $\mu \mathrm{g} / \mathrm{kg}$ i.v.), 5 lateral geniculate neurons $(35.7 \%)$ showed enhanced responses as compared to control but those neurons were not depressed by scopolamine in doses of $0.5 \mathrm{mg} / \mathrm{kg}$ i.v. 
Nine neurons $(64 \cdot 3 \%)$ excited by reticular formation stimulation were not enhanced by nicotine in doses of $25 \mu \mathrm{g} / \mathrm{kg}$ i.v. (Fig. 4).

Effects of bilateral eye enucleation. Four cats were subjected to bilateral eyeball enucleation. Under diethyl ether-air anesthesia both optic nerves were exposed and subsequently cut. Control responses and experimental procedures were the same as above prior to and after optic nerve transection. The spontaneous firing rate was tremendously increased following enucleation. Responses to optic tract stimuli were markedly enhanced as well (Fig. 4). The post-stimulation discharge pattern was periodic every $1.5-1.8 \mathrm{msec}$ and continued for about $10 \mathrm{msec}$. The responses to reticular formation stimulation were slightly enhanced $1.5 \mathrm{msec}$ after stimulation and inhibited about 2-3 msec after the enhancement (Fig. 4). After enucleation the maximal firing rates were not consistently altered by i.v. nicotine but were reduced by scopolamine (Fig. 5).

\section{Effects of physostigmine}

Modification of mean spontaneous firing rate. Facilitation of unit responses was usually observed $5 \mathrm{~min}$ after administration of $25 \mu \mathrm{g} / \mathrm{kg}$ i.v. of physostigmine. Nineteen lateral geniculate neurons were recorded. After physostigmine the mean spontaneous firing rate \pm S.E. was $41 \cdot 4 \pm 4.0 / \mathrm{sec}$ compared to the control level of $22 \cdot 3 \pm 1 \cdot 9 / \mathrm{sec}$. This increase was statistically significant $(P<0 \cdot 001)$. Following physostigmine no consistent changes in mean arterial BP were observed.

Modification of unit responses to single optic tract stimuli. Fourteen units which were excited by optic tract stimulation showed enhanced discharge following $25 \mu \mathrm{g} / \mathrm{kg}$ i.v. physostigmine. However, their response latency did not change as compared to controls (Fig. 3). Neurons facilitated by physostigmine showed exaggerated periodic bursts at intervals of $2 \cdot 5-5 \mathrm{msec}$ which were also seen in the controls (Fig. 6). The enhanced responsiveness induced by physostigmine was antagonized by scopolamine.

Modification of unit responses to single stimuli to the reticular formation. The discharge rate of 14 neurons was enhanced by the administration of $25 \mu \mathrm{g} / \mathrm{kg}$ i.v. physostigmine. In addition to single shocks, trains of stimuli (pulses $0.1 \mathrm{msec}, 250 \mathrm{~Hz} / \mathrm{sec}$, train duration 50 $\mathrm{msec}$ ) were even more effective in facilitating single lateral geniculate units. The effects lasted about $100-120 \mathrm{msec}$ but their response latency did not change. Physostigmine further enhanced their discharge rate.

\section{Effects of scopolamine}

Effects on mean spontaneous firing rate. The mean spontaneous firing rate of 14 lateral geniculate neurons was recorded $5 \mathrm{~min}$ after $0.5 \mathrm{mg} / \mathrm{kg}$ scopolamine. The mean spontaneous firing rate \pm S.E. was $20 \cdot 0 \pm 2 \cdot 7 / \mathrm{sec}$. There was a tendency for a shift to the lower frequencies but the mean decrease was very slight (Fig. 1). However, burst discharges were not observed following scopolamine.

Modification of unit responses to single optic tract stimuli. Fourteen neurons were recorded. Following scopolamine $(0.5 \mathrm{mg} / \mathrm{kg}$ i.v. $)$, there was no increase to optic tract stimulation. Five $(35.7 \%$ ) neurons had depressed firing rates and 9 neurons $(64.3 \%)$ did not change their firing rate to optic nerve tract stimulation (Table 1). These effects of scopolamine continued for at least $1 \mathrm{hr}$ or more.

Modification of unit responses to reticular stimuli. Nine neurons showed depressed firing rates and 5 did not change their firing rate to reticular formation stimulation following 0.5 $\mathrm{mg} / \mathrm{kg}$ i.v. of scopolamine. 


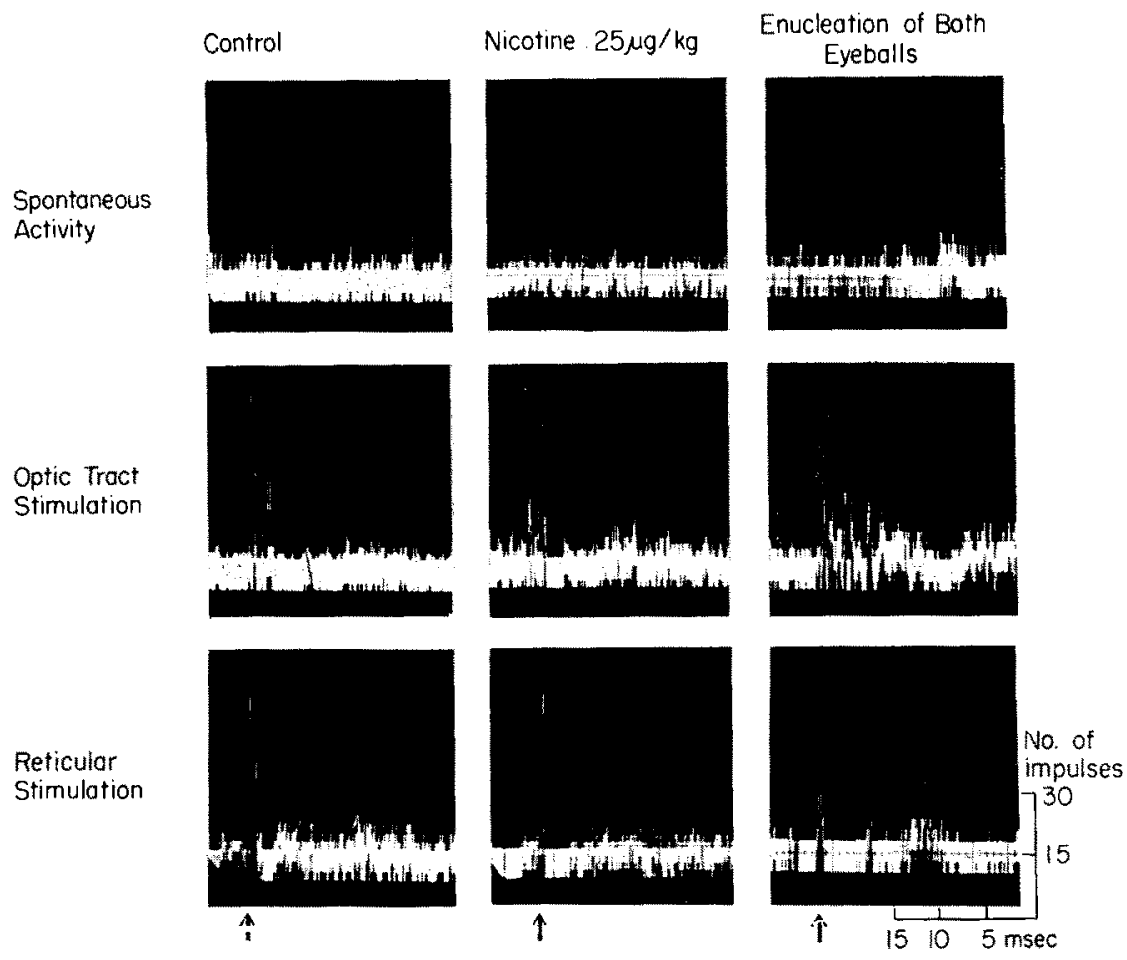

FIg. 4. Post-stimulus time histogram of a lateral geniculate neuron after nicotine and bilateral enucleation. The figure illustrates displays from a CAT 400 computer. A mean of 30 sweeps was obtained. Each section $-0.78 \mathrm{msec}$. The number of impulses and the time interval are shown in the calibration bars. The stimulus artifact is shown at the arrows below each histogram except for the upper row which records spontaneous activity. Note that nicotine increased the frequency of firing to optic tract and reticular stimulation. Bilateral enucleation caused a very marked increase in neuronal discharge, especially to optic tract stimulation. In each case recordings were made under dark conditions.

\section{Control}

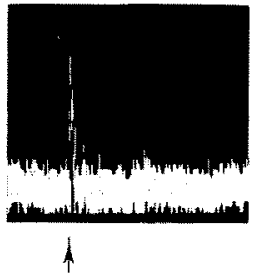

Enucleation

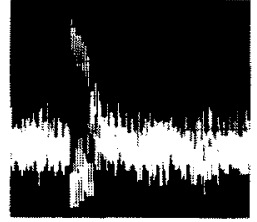

(
Scopolomine

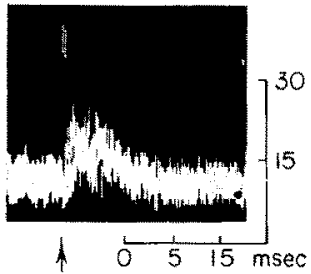

Fro. 5. Post-stimulus time histogram of the response of a lateral geniculate neuron to single shock optic tract stimuli. The time histograms are similar to those described in Fig. 4 . Note that bilateral enucleation caused a marked increase in spontaneous and evoked neuronal discharge. This is reduced but somewhat prolonged following $0.5 \mathrm{mg} / \mathrm{kg}$ of scopolamine.

Calibration as noted. 


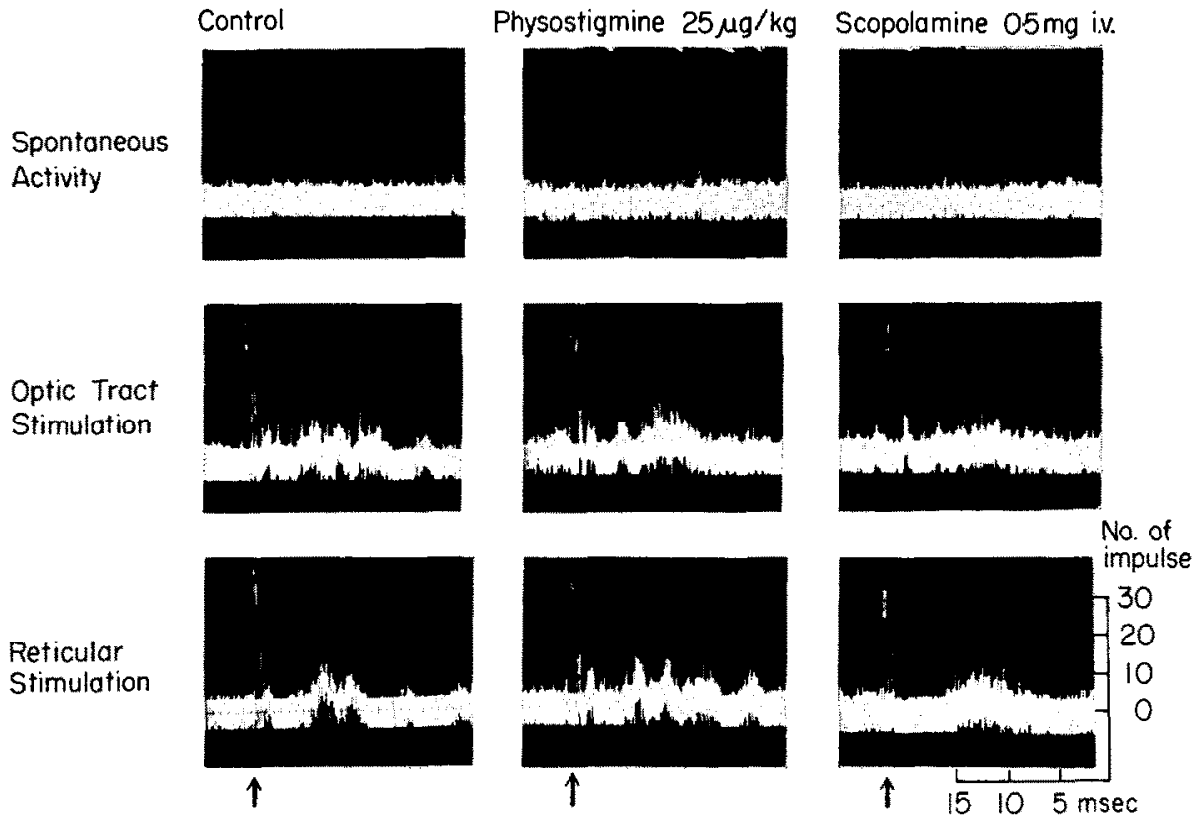

Fig. 6. Post-stimulus time histogram of a lateral geniculate ncuron before and after physostigmine and scopolamine. The time histograms are similar to those described in Fig. 4. Note that 5 min after physostigmine there was an increase in spontaneous discharge and the early components were enhanced after optic tract and reticular stimulation with a redistribution of period bursts. Ten minutes after physostigmine the administration of scopolamine restored the histogram toward control. Calibration as noted. 
TABLE 1. THE SAME UNIT RESPONSES TO OPTIC TRACT AND RETICULAR FORMATION STIMULATION BEFORE AND AFTER ADMINISTRATION OF VARIOUS DRUGS

\begin{tabular}{|c|c|c|c|c|c|}
\hline Site of stimulation & $\begin{array}{l}\text { Response } \\
\text { patterns }\end{array}$ & $\begin{array}{l}2 \text { min after } \\
\text { nicotine } \\
25 \mu \mathrm{g} / \mathrm{kg} \text { i.v. }\end{array}$ & $\begin{array}{c}5 \text { min after } \\
\text { physostigmine } \\
25 \mu \mathrm{g} / \mathrm{kg} \text { i.v. }\end{array}$ & $\begin{array}{c}5 \mathrm{~min} \text { after } \\
\text { scopolamine } \\
0.5 \mathrm{mg} / \mathrm{kg} \text { i.v. }\end{array}$ & $\begin{array}{c}\text { No. of } \\
\text { units }\end{array}$ \\
\hline Optic tract & $\begin{array}{l}\text { Excited } \\
\text { Excited }\end{array}$ & $\begin{array}{l}\text { Enhanced } \\
\text { No effect }\end{array}$ & $\begin{array}{l}\text { Enhanced } \\
\text { Enhanced }\end{array}$ & $\begin{array}{l}\text { No effect } \\
\text { Depressed }\end{array}$ & $\begin{array}{l}9 \\
5\end{array}$ \\
\hline Reticular formation & $\begin{array}{l}\text { Excited } \\
\text { Excited }\end{array}$ & $\begin{array}{l}\text { Enhanced } \\
\text { No effect }\end{array}$ & $\begin{array}{l}\text { Enhanced } \\
\text { Enhanced }\end{array}$ & $\begin{array}{l}\text { No effect } \\
\text { Depressed }\end{array}$ & $\begin{array}{l}5 \\
9\end{array}$ \\
\hline
\end{tabular}

Unit responses to optic tract and reticular formation stimulation before and after administration of nicotine, physostigmine and scopolamine in sequence. The experimental schedule was as follows: (a) Identification of lateral geniculate units as P-cells, (b) recording control responses to optic tract and reticular stimulation, (c) repeating procedure " $b$ " 2 min after administration of $25 \mu \mathrm{g} / \mathrm{kg}$ i.v. nicotine, (d) a 20 -min interval for recovery, (e) repeating procedure " $b$ " $5 \mathrm{~min}$ after administration of $25 \mu \mathrm{g} / \mathrm{kg}$ i.v. physostigmine, (f) another recording period $10 \mathrm{~min}$ later, and $(\mathrm{g})$ repeating procedure " $\mathrm{b}$ " $5 \mathrm{~min}$ after administration of $0.5 \mathrm{mg} / \mathrm{kg}$ i.v. scopolamine.

Optic tract stimulation. Fourteen neurons showed enhanced discharge to optic tract stimulation following physostigmine. Most of these were unaffected by the administration of nicotine but were depressed by scopolamine. Another 5 neurons showed enhanced discharge following nicotine. These neurons did not change their responses following scopolamine.

Reticular formation stimulation. Fourteen neurons showed enhanced responses after physostigmine but 9 of these did not show any change following nicotine. These 9 were also depressed following scopolamine (Fig. 7). Five other neurons which did not change their firing rates following scopolamine were enhanced by nicotine. These data suggest a cholinergic modulation on the lateral geniculate neuron to reticular formation stimulation.

\section{DISCUSSION}

Hubel (1960), Taira and OKUdA (1962) and Levick and Williams (1964) observed that the discharge patterns of lateral geniculate neurons were regulated by the level of activity of the reticular formation during activation, non-rapid-eye-movement sleep or general anesthesia. By using bilaterally enucleated cats under unrestrained conditions, SAKAKURA and IWAMA (1967) also observed that the discharge patterns of lateral geniculate neurons were regulated by the level of reticular formation activation. SUZUKI and TAIRA (1962) reported that the discharge patterns of "on" or "off" geniculate neurons to light stimulation were modified by reticular activity, but optic nerve fiber units were not.

In the present study many lateral geniculate neurons were excited following physostigmine and showed increased responses to reticular stimulation. Furthermore, the enhanced responsiveness of these cells induced by physostigmine was abolished by scopolamine suggesting they were of the muscarinic type.

Other lateral geniculate neurons were also excited by nicotine as well as physostigmine, and showed an increased response to optic tract stimulation. Units elicited by optic tract stimulation were not depressed by scopolamine. However, in these neurons, the facilitatory effect of reticular formation stimulation was depressed completely by scopolamine. 
Control

Optic troct
Stimul
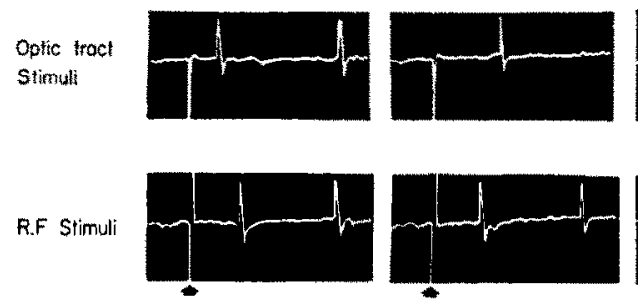

Scopolomine $05 \mathrm{mg} / \mathrm{kg} \mathrm{iv}$
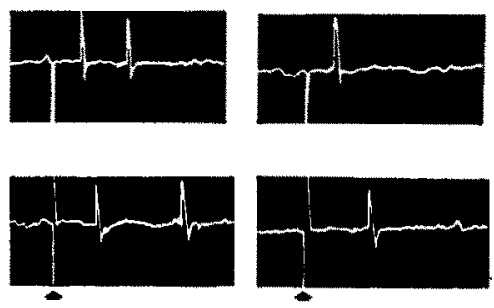

$-$
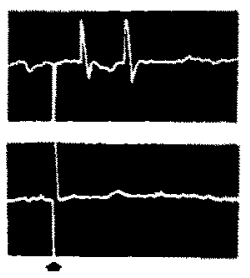
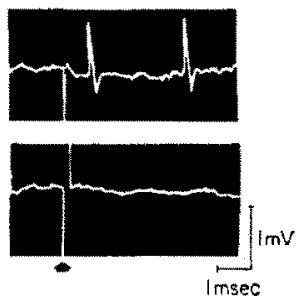

Fig. 7. Effects of scopolamine on single unit discharge of a lateral geniculate neuron to optic tract and reticular stimulation. In the upper two sets of records the response of a neuron to single shocks to the optic tract and reticular formation are shown in sequence. Note that after $0.5 \mathrm{mg} / \mathrm{kg} \mathrm{i.v.} \mathrm{scopolamine} \mathrm{the} \mathrm{responses} \mathrm{to} \mathrm{optic} \mathrm{tract} \mathrm{stimulation} \mathrm{were} \mathrm{essentially} \mathrm{unchanged,}$ but markedly reduced to reticular stimulation. Calibration as noted.

The facilitatory effect of reticular formation stimulation on lateral geniculate neurons has been observed by SuzuKI and TAIRA (1962) and OGAWA (1963). In the present study, this facilitatory effect was strongly enhanced by physostigmine and blocked by scopolamine, but was not changed by nicotine. ADRIAN and MATTHEws (1927a,b, 1928) reported that the frequency of unitary discharges on optic nerve fibers of the conger eel were altered by the intensity of light stimulation. This was confirmed by Hartuine (1938). HubeL and WieseL. (1962), ERULlKar and FilLENZ (1958) and SUZUKI and KaTo (1966) reported that there was some binocular interaction on the single neurons of the visual cortex. A small portion of the cells were color-coded and some of the neurons could discriminate the moving target (HUBEL and WIESEL, 1968). Since all visual inputs from the retina to the cerebral cortex must pass through the lateral geniculate nucleus and since the connection between optic nerve terminals and lateral geniculate neurons is not one-to-one (HUBEL and WIEsEL, 1961), it seems logical that the function of the lateral geniculate neurons should be complicated and that the chemical transmitters or modulators may differ from each other.

An excitatory action of acetylcholine applied by local iontophoretic injection on lateral geniculate neurons was reported by CurTis and DAvis (1963) and PhILIIs, TEBECIS and York (1967b). The typical response of acetylcholine applied iontophoretically on geniculate neurons is very slow to develop, frequently taking up to $60 \mathrm{sec}$. The characteristics of this excitant action differ from those observed in the excitation of Renshaw cells by acetylcholine (McCane, Phillis and Westermann, 1966). Phillis et al. (1967b) concluded that acetylcholine was not the major excitatory synaptic transmitter released at optic nerve terminals by orthodromic volleys. The present data certainly support this conclusion. Intracarotid injection of 50-100 $\mu \mathrm{g}$ physostigmine was shown to enhance the amplitude of the postsynaptic responses to optic nerve stimulation (DAvid, Murayama, MaChNe and UNNA, 
1963). The present data show that physostigmine enhanced unit responses to optic tract stimulation. Although it is obvious that acetylcholine cannot be the excitatory synaptic transmitter released at optic nerve terminals by orthodromic volleys, it still may act as a facilitatory modulator especially from the reticular formation. PHILLis et al. (1967a) suggested that inhibitory effects of reticular stimulation were mediated by a monoaminergic projection system and the facilitatory effects of reticular stimulation were mediated by a cholinergic one. The present data support the hypothesis of a cholinergic modulatory system which is mostly facilitatory. Furthermore, it would seem that about $2 / 3$ of the lateral geniculate neurons show a muscarinic response and another $1 / 3$ a nicotinic cholinergic response under dark conditions. It is important to remember that tonic inhibitory effects from the retina control lateral geniculate neurons under dark conditions. After retinal blockade (BISHOP et al., 1964; SUZUKI, 1967; ARDUINI and HIRAO, 1960) or enucleation of both eyeballs (ERULKAR and FILLENZ, 1958; NAKAI and DomINo, 1968) the evoked response in the visual cortex and lateral geniculate is tremendously enhanced.

SAKAKURA and IWAMA (1967) reported that the spontaneous firing rate of lateral geniculate neurons in the chronic cat is very low $(3 \cdot 7 \pm 2 \cdot 7 / \mathrm{sec})$ in non-rapid-eye-movement sleep. During arousal this increases to $9 \cdot 9 \pm 4.9 / \mathrm{sec}$. High intraocular pressure in both eyeballs depresses the firing discharge rate of lateral geniculate neurons (SUZUKI and ICHIJ, 1967) but post-synaptic potentials evoked by optic tract stimulation in lateral geniculate bodies are increased. OGDEN and BRAWN(1964) suggested that the efferent fibers from the lateral geniculate to the retinal amacrine cells caused inhibitory effects on the ganglion cells.

In the present study, enucleation of both eyeballs during recording of the same units showed that the firing discharge rate and optic stimulation response were tremendously increased but reticular stimulation caused only a slight increase. These effects suggest that there was some feedback or presynaptic inhibition (SUzUKI and KATO, 1966, 1967) between the lateral geniculate and the retina. We have not ruled out an action of physostigmine, nicotine or scopolamine on such a system. However, although consistent nicotine effects were not observed after enucleation, scopolamine clearly reduced the frequency of optic evoked units indicating an action beyond the retina within the brain. Finally, it should be emphasized that recording single units from the lateral geniculate after i.v. administration of various drugs does not in any way prove that the drugs are acting at the lateral geniculate. For example, drugs may alter the threshold of response to electrical stimulation of the reticular formation, etc. particularly at sites relatively distant from the electrode tip. Other neuropharmacological techniques must be used such as iontophoretic drug application to localize the precise site of drug effect. This approach is currently being pursued and will be the subject of a later communication.

\section{REFERENCES}

ADRIAN, E. D. and MATthews, R. (1927a). The action of light on the eye. Part 1. The discharge of impulses in the optic nerve and its relation to the electric change in the retina. J. Physiol., Lond. 63: 378-414.

Adrian, E. D. and Matthews, R. (1927b). The action of light on the eye. Part 2. The process involved in retinal excitation. J. Physiol., Lond. 64: 277-301.

Adrian, E. D. and Matrhews, R. (1928). The action of light on the eye. Part 3. The interaction of retinal neurons. J. Physiol, Lond. 65: 273-298.

AmIN, A. H., CRAWFORD. T. B. B. and GADDEN, J. H. (1954). The distribution of substance p and 5-hydroxytryptamine in the central nervous system of the dog. J. Physiol., Lond. 126:596-618.

ANGEl, A., MAGNI, F, and Strata, P. (1965a). Evidence for presynaptic inhibition in the lateral geniculate body. Nature, Lond. $208:$ : 495-496.

ANGEL, A., MAGNI, F. and Strata, P. (1965b). Excitability of intra-geniculate optic tract fibers after reticular stimulation in the mid-pontine pretrigeminal cat. Archs ital. Biol. 103: 668-693. 
Angel, A., Magni, F. and Strata, P. (1967b). The excitability of optic nerve terminals in the lateral geniculate nucleus after stimulation of visual cortex. Archs ital. Biol. 105: 104-117.

Angel, A. and Strata, P. (1967a). Relationship between cortical activity and the excitability of optic nerve terminals in the lateral geniculate body. Brain Res. 5: 501-503.

ARduinI, A. and Hirao, T. (1960). Enhancement of evoked responses in the visual system during reversible retinal inactivation. Archs ital. Biol. 98: 182-205.

BISHOP, P. O. (1953). Synaptic transmission. An analysis of the electrical activity of the lateral geniculate nucleus in the cat after optic nerve stimulation. Proc. Soc. Ser. B. 141: 362-392.

Bishop, P. O., Burke, W. and Davis, R. (1962). Single unit recording from antidromically activated optic radiation neurons. J. Physiol., Lond. 162: 432-445.

Bishop, P. O., Levick, W. R. and WiLliams, W. O. (1964). Statistical analysis of the dark discharge in lateral geniculate of cat. J. Physiol., Lond. 170: 598-612.

BISHOP, P. O. and MACLEOD, J. G. (1954). Nature of potentials associated with synaptic transmission in the lateral geniculate of the cat. $J$. Neurophysiol. 17: 387-414.

Bishop, G. H. and O'Leary, J. (1938). Potential records from the optic cortex of the cat. J. Neurophysiol. 1: $391-404$.

BishoP, G. H. and O'LeARY, J. (1940). Electrical activity of the lateral geniculate body of cats following optic nerve stimuli. $J$. Neurophysiol. 3: 308-322.

Bogdanski, D. F., Weissbach, H. and Udenffriend, S. (1957). The distribution of serotonin, 5-hydroxytryptamine decarboxylase and monoamine axydase in brain. $J$. Neurochem. 1: 272-278.

Boudreau, J. C., Bierer, P. and Kaufman, J. (1968). A gold plated platinum tipped, stainless steel microelectrode. Elestroenceph. clin. Neurophysiol. 25: 286-287.

Burgen, A. S. V. and Chipman, L. M. (1951). Cholinesterase and succinic dehydrase in the central nervous system of the dog. J. Physiol., Lond. 114: 296-305.

CHI, C. C. and FLYNN, J. P. (1968). The effects of hypothalamic and reticular stimulation on evoked responses in the visual system of the cat. Electroenceph. clin. Neurophysiol. 24: 343-356.

Chow, K. L., LindSLEY, D. F. and GOLLENDER, M. (1968). Modification of response pattern of lateral geniculate neurons after paired stimulation of contralateral and ipsilateral eyes. J. Neurophysiol. 31: 729-739.

Cobin, L. B., Leeder, S. and PAllord, J. (1965). Smooth muscle stimulants in extracts of optic nerves, optic tracts and lateral geniculate bodies of sheep. Br. J. Pharmac. Chemother. 25: 295-360.

CurTIS, D. R. and DAvis, R. (1962). Pharmacological studies upon neurons of the lateral geniculate nucleus of the cat. Br.J. Pharmac. Chemother. 18: 217-246.

Curtis, D. R. and DAvIs, R. (1963). The excitation of lateral geniculate neurons by quaternary ammonium derivates. J. Physiol., Lond. 165: 62-82.

David, J. P., Murayama, S., Machne, X. and UNNA, K. R. (1963). Evidence supporting cholinergic transmitter at the lateral geniculate body of the cat. Int. J. Neuropharmac. 2: 113-125.

Deffenu, G., BertaccinI, G. and Pepeu, G. (1967). Acetylcholine and 5-hydroxytryptamine levels of the lateral geniculate body and superior colliculus of the cat after visual deafferentation. Expl. Neurol. 17: 203-209.

Erulkar, S. D. and Fillenz, M. (1958). Patterns of discharge of single units of the lateral geniculate body of the cat in response to binocular stimulation. J. Physiol., Lond. 14: 6-7.

Feldberg, W. and VOGT, M. (1948). Acetylcholine synthesis in different regions of the central nervous system. J. Physiol., Lond. 107: 372-381.

FUXE, K. (1965). Evidence from the existence of monoamine neurons in the central nervous system. IV. Distribution of monoamine terminals in the central nervous system. Acta physiol. scand. 64, suppl. 247: 37-85.

Gerstein, G. L. and LiAng, N. Y.-S. (1960). An approach to the quantitative analysis of electrophysiological data from single neurons. Biophysiol, J. 1: 15-28.

HARTLINE, H. K. (1938). The response of single optic nerve fibers of the vertebrate to illumination of the retina. Am. J. Physiol. 121 : 400-415.

Hebs, C. O. and Silver, A. (1959). Cholinesterases in the central nervous system of man and some other mammals. J. Physiol., Lond. 134: 718-728.

HubEL, D. H. (1957). Tungsten micro electrode for recording from single units. Science, N.Y. 25: 549-550.

Hubel, D. H. (1960). Single unit activity in lateral geniculate body and optic tract of unrestrained cats. $J$. Physiol., Lond. 150: 91-104.

Hubel, D. H. and Wresel, T. N. (1961). Integrative action in the cat's lateral geniculate body. J. Physiol., Lond. 155: 385-398.

Hubel, D. H. and Wiesel, T. N. (1962). Receptive fields, binocular interaction and functional architecture in the cat's visual cortex. J. Physiol, Lond. 160: 104-154.

HUBEL, D. H. and WIESFL, T. N. (1968). Receptive fields and functional architecture of monkey striate cortex. J. Physiol., Lond. 195: 215-243. 
Iwama, K., Sakakura, H. and Kasamatsu, T. (1965). Presynaptic inhibition in the lateral geniculate body induced by stimulation of the cerebral cortex. Jap. J. Physiol. 15: 310-322.

Kahn, H. F., MaGni, F. and Pillai, R. V. (1967). Depolarization of optic fiber endings in the lateral geniculate body. Archs ital. Biol. 105: 573-582.

LEVICK, W. R. and WILliams, W. O. (1964). Maintained activity of lateral geniculate neurons in darkness. J. Physiol., Lond. 170: 582-597.

LoNG, R. C. (1959). Modification of sensory mechanism by subcortical structures. J. Neurophysiol. 22: 412-427.

McCane, I., Phillis, J. W. and Westermann, R. A. (1966). Responses of thalamic neurons to iontophoretically applied drugs. Nature, Lond. 209: 715-716.

McIllwain, J. T. and Creutzfeldt, O. D. (1967). Microelectrode study of synaptic excitation and inhibition in the lateral geniculate nucleus of the cat. J. Neurophysiol. 30: 1-20.

NAKAI, Y. and Domino, E. F. (1968). Reticular facilitation of visual evoked responses by optic tract stimulation before and after enucleation. Expl. Neurol. 22: 532-544.

NAKAI, Y. and Domino, E. F. (1969). Differential effects of pentobarbital, ethyl alcohol, and chlorpromazine in modifying facilitation of visual evoked responses in the cat. Int. J. Neuropharmac. 8: 61-72.

OGAWA, T. (1963). Midbrain reticular influences upon single neurons in lateral geniculate nucleus. Science, N.Y. $139: 343-344$.

OGDEN, T. E. and BRAWN, K. T. (1964). Intraretinal responses of the cynamolgus monkey to electrical stimulation of the optic nerve and retina. $J$. Neurophysiol. 27:682-705.

Phillis, J. W., Tebecis, A. K. and York, D. H. (1967a). The inhibitory action of monoamines on lateral geniculate neurons. J. Physiol., Lond. 190: 563-581.

Phillis, J. W., Tebecis, A. K. and York, D. H. (1967b). A study of cholinoceptive cells in the lateral geniculate nucleus. J. Physiol., Lond. 192: 695-713.

Sakakura, H. and Iwama, K. (1967). Effects of bilateral eye enucleation upon single unit activity of the lateral geniculate body in free behaving cats. Brain Res. 6: 667-678.

SATINSKY, D. (1968). Reticular influences on lateral geniculate neuron activity. Electroenceph. clin. Neurophysiol. 17: 203-209.

Shute, C. C. D. and Lewis, P. D. (1963). Cholinesterase-containing systems of brain of the rat. Nature, Lond. 199: 1160-1164.

Shute, C. C. D. and Lewis, P. D. (1966). Cholinergic and monoaminergic systems of the brain. Nature, Lond. 212: 710-711.

Snider, S. R. and Niemer, W. T. (1961). A stereolaxic atlas of the cal brain. Univ. of Chicago Press, Chicago, Illinois.

Suzuki, H. (1967). Effect of reversible retinal blockade on population response of the lateral geniculate nucleus. Jap.J. Physiol. 17: 335-347.

Suzukı, H. and ICHıo, M. (1967). Tonic inhibition in cat lateral geniculate nucleus maintained by retinal spontaneous discharge. Jap. J. Physiol. 17: 599-612.

Suzuki, H. and Kato, E. (1966). Binocular interaction at cat's lateral geniculate body. J. Neurophysiol. 29: 909-920.

Suzuki, H. and Kato, E. (1967). Post synaptic inhibition in lateral geniculate nucleus and its relation to recovery cycle of geniculate population response. Tohoku J. exp. Med. 92: 271-279.

Suzuki, H., Taira, N. and Motokawa, K. (1960). Spectral response curves and receptive fields of preand post-geniculate fibers of the cat. Tohoku J. exp. Med. $71: 401-414$.

Suzuki, H. and TAIRA, N. (1962). Effect of reticular stimulation upon synaptic transmission in cat's lateral geniculate body. Jap. J. Physiol. 11 : 641-655.

TAIRA, N. and OKuDA, J. (1962). Sensory transmission in visual pathway in various arousal states of cat. Tohoku J. exp. Med. 78: 69-97.

VAstola, E. F. (1957). Antidromic action potentials in lateral geniculate body. J. Neurophysiol. $20: 169-187$.

VOGT, M. (1954). The concentration of sympathin in different parts of the central nervous system under normal conditions and after administration of drugs. J. Physiol., Lond. 123:451-481. 